\title{
Pharmacogenomics and Biochemical Influences of Walnuts on Diabetic Tissue
}

\author{
Nermin El-Halawany ${ }^{1}$, Amal Z. Barakat ${ }^{2}$, Inas S. Ghaly ${ }^{1}$ and Sahar Ahmed ${ }^{1, *}$ \\ ${ }^{I}$ Cell Biology Department, Genetic Engineering Division, National Research Center, Cairo, Egypt; ${ }^{2}$ Molecular Biology \\ Department, Genetic Engineering Division, National Research Center, Cairo, Egypt
}

\begin{abstract}
Medicinal therapy requires careful assessment of effective treatment offering an acceptable safety over human health. This study aimed to evaluate the influence of walnuts diet on streptozotocin-induced diabetic mice. Comprehensive systems of biochemical markers and genomic screening were used to achieve this task. Experimental animals were divided into four groups (negative and positive control, diabetic group and diabetic group fed on walnuts diet). Diabetes was induced by i.p. injection of streptozotocin (STZ) for 3 successive days. Biomarkers assay, gene expression analysis, comet assay, quantitation of DNA fragmentation and micronucleus assay were investigated. The results suggested that walnuts could act as diabetic therapy without adverse effects at metabolic activity and molecular levels in diabetic mice.
\end{abstract}

Keywords: Biomarker, gene expression, DNA damage, DNA fragmentation, comet assay, micronucleus, walnuts.

\section{INTRODUCTION}

Diabetes mellitus is a chronic metabolic disorder disease, widely spread in human, characterized by hyperglycemia resulting from defects in insulin secretion, insulin action, or both. The chronic hyperglycemia was found to increase the production of oxygen free radicals (OFRs) that is associated with long-term damage, dysfunction, and failure of various organs, especially the eyes, kidneys, nerves, heart, and blood vessels $[1,2]$. Under normal conditions adequate protection is provided by the antioxidant systems, a number of major cellular antioxidant defense mechanisms exist to neutralize the damaging effects of these free radicals. If the OFRs are not quenched by antioxidants, these highly reactive compounds will react and potentially alter the structure and function of several cellular or extracellular components, such as cell membranes, lipoproteins, proteins, carbohydrates, RNA and DNA [3-6]. The increase in the level of OFRs in diabetes was reported to be due to their increased production and/or decreased destruction by non-enzymic and enzymic antioxidants. Catalase (CAT), superoxide dismutases (SODs), and glutathione (GSH) is the major enzymic and non-enzymic anti-oxidants that remove and protect the cells from the free radicals $[7,8]$.

Currently available synthetic antidiabetic agents produce serious side effects, such as hypoglycaemic coma and hepatorenal disturbances [9]. Moreover, they are not safe to be used during pregnancy [10]. Recently, it has been assumed that many dietary plants contain numerous types of antioxidants with different properties. Many of these antioxidants cooperate in oxidative stress reduction. To test this hypothesis, it was useful to identify dietary plants with high total antioxidant content.

*Address correspondence to this author at the Cell Biology Department, Genetic Engineering and Biotechnology, Division, National Research Center., El Buhouth St., postal code 12311, Dokki, Giza, Egypt; Tel: (+202) 33371362; Fax: (+202) 33370931; E-mail: selnahta@yahoo.com
Several nuts are among the dietary plants with the highest content of total antioxidants. Vinson and Cai [11] reported that a gram of walnuts (Juglans regia L.) contains nearly 70 units of polyphenols, a form of antioxidant more than any of the other nuts. The polyphenols were also up to 15 times more potent than those found in other sources like vitamin E. Walnuts extracts are superior in binding with lower density lipoprotein (LDL) and inhibiting its oxidation than other nuts. The 14 walnut polyphenols have superoxide dismutase (SOD)-like activity with EC50 21.4-190 $\mu \mathrm{M}$ and a remarkable radical scavenging effect against 1, 1-diphenyl-2picrylhydrazyl [12].

Pharmacogenomics can be defined as the sum of the word's parts: the study and application of genetic factors related to the body's response to drugs, or pharmacology. Scientists are increasingly learning more about the interaction between drugs and human genetics in order to develop therapeutic medicine more efficient without adverse effects. At the molecular level, the metabolite can bind to the protein's active site, which can include ligand-binding sites, conformation-altering sites, or catalytic sites. This effect can then be propagated through biochemical pathways to produce a cellular and finally, systemic physiological effect [13, 14].

Although various phytochemical constituents and diverse medicinal activities have been attributed to walnuts, according to our knowledge, the biochemical and pharmacogenomics studies have not been carried out to study whether walnuts can protect against oxidative stress induced diabetes in different tissues. This study aimed to evaluate the adverse effect of walnuts mixture diet on streptozotocin-induced diabetic mice. Comprehensive systems of biochemical markers and genomic screening were used to achieve this task. Assessment of antioxidant biomarkers activity [Superoxide dismutases (SOD), Catalase (CAT), Glutathione (GSH) and lipid peroxidation], expression level of $S O D, C A T$ and $G P x$ 
genes and DNA damage using DNA fragmentation, micronucleus and comet assays were investigated.

\section{MATERIAL AND METHODS}

\subsection{Animals}

Male Swiss albino mice weighing 25-30 g were obtained from animal house (National Research Center, Giza Egypt). The animals were maintained under standard laboratory conditions. Food and water were provided ad libitum.

\subsection{Preparation of Walnuts Diet}

Fresh walnuts were obtained from the market and used for the study. Twenty-five grams $(25 \mathrm{~g})$ of ground walnuts were mixed with $75 \mathrm{~g}$ of normal mice chow feed (basal diet) in a ratio of $1: 3$ by weight, respectively.

\subsection{Experimental Design}

Twenty eight mice were classified into four groups (7 animals each) and subjected to treatment as follows:

Group I: Received $1 \mathrm{~mL}$ distilled water per $100 \mathrm{~g}$ body weight (bwt) per day by oral gavage and served as negative control group, fed on basal diet.

Group II: Fed on a walnuts diet daily for 30 days as positive control group.

Group III: Injected with streptozotocin (STZ) intraperitoneal (i.p.) in a dose of $60 \mathrm{mg} / \mathrm{kg}$ bwt for 3 successive days and served as a diabetic group, fed on basal diet.

Group IV: Injected with STZ, i.p. in a dose of $60 \mathrm{mg} / \mathrm{kg}$ bwt for 3 successive days and fed on a walnuts diet daily for 30 days.

Twenty-four hour after the end of experiment, the animals were anaesthetized using ether or sacrificed by cervical decapitation.

\subsection{Induction of Diabetes}

Type 1 diabetes was induced by i.p. injection of streptozotocin (STZ) in a dose of $60 \mathrm{mg} / \mathrm{kg}$ bwt dissolved in $0.05 \mathrm{M}$ citrate buffer ( $\mathrm{pH} 4.5)$ for 3 successive days [15].

\subsubsection{Evaluation of Diabetic State}

Diabetes was confirmed after $72 \mathrm{~h}$ of streptozotocin injection, the blood samples were collected via retro-orbital venous plexus and serum glucose levels were estimated by enzymatic GOD-PAP (Glucose oxidase peroxidase) diagnosis kit method. Mice were considered diabetic when the blood glucose concentrations increased to 200 or more $\mathrm{mg} / \mathrm{dl}$.

\subsection{Biomarkers Assay}

\subsubsection{Tissue Collection}

Thirty days after the beginning of treatments, all the animals from each group were sacrificed. Liver and kidney of each animal were removed, washed with ice-cold sterile saline with $0.16 \mathrm{mg} / \mathrm{ml}$ heparin, dried and frozen in liquid nitrogen. The organs were stored at $-80^{\circ} \mathrm{C}$ until analysis. Tis- sue samples were homogenized in ice cold lysis buffer containing $50 \mathrm{mM}$ potassium phosphate buffer $(\mathrm{pH} \mathrm{7.0)}$ and 2 $\mathrm{mM}$ EDTA. The homogenates were centrifuged at $4,000 \mathrm{rpm}$ for 15 minutes and supernatants from each liver and kidney were assayed for the determination of protein lipid peroxide and reduced glutathione concentrations and activity levels of catalase and superoxide dismutase.

\subsubsection{Biochemical Analysis}

Total protein determination was quantified by the method of Bradford [16] using bovine serum albumin as standard. The activity of catalase (CAT) was assayed following the method described by Aebi [17]. Supernatant was tested for lipid peroxidation index, superoxide dismutase activity and glutathione (GSH) content, in both liver and kidney tissues using the Bio-diagnostic kits (Egypt), following manufacturer instructions.

\subsection{Gene Expression Analysis}

\subsubsection{RNA Extraction and Reverse Transcription (RT)}

RNA was isolated from kidney tissues of all investigated groups using Biozol reagent (BioFlux) following manufacturer instructions. RNA was quantified by spectrometry and RNA integrity was evaluated on $1 \%$ agarose gels containing formaldehyde and ethidium bromide. First strand cDNA template was synthesized by mixing $1 \mu \mathrm{g}$ RNA and $5 \mu \mathrm{M}$ of the (dT)11- primer. The mixtures were heated for $5 \mathrm{~min}$ at $65^{\circ} \mathrm{C}$ and placed on ice to cool. Then 1x RT buffer, 200 units SuperScript RT (Fermentase), $25 \mu \mathrm{M}$ dNTP, and $10 \mathrm{mM}$ dithiothreitol (DTT) were added and incubated for $1 \mathrm{~h}$ at $40^{\circ} \mathrm{C}$ in a final volume of $20 \mu \mathrm{l}$. After heat inactivation for 5 min at $70^{\circ} \mathrm{C}$ the cDNA was stored at $-20^{\circ} \mathrm{C}$ for the subsequent PCR reactions. To test the genomic DNA contamination, RNA and cDNA were used as template in a PCR reaction using primers of $\beta$-actin

\subsubsection{Polymerase Chain Reaction (PCR)}

The sequences and sizes of GPx, SOD, CAT and $\beta$-actin primers are given in (Table 1) $[18,19]$. The reverse transcribed products (cDNAs) were subjected to $\mathrm{PCR}$ at $94^{\circ} \mathrm{C}$ for $4 \mathrm{~min}$, and 35 amplification cycles, each cycle consisted of denaturation at $94^{\circ} \mathrm{C}$ for $30_{\mathrm{S}}$, annealing at $56^{\circ} \mathrm{C}(S O D$ and $G P x)$ or $55^{\circ} \mathrm{C}(C A T)$ for $1 \mathrm{~min}$, and extension at $72^{\circ} \mathrm{C}$ for 1 min followed by the final extension at $72^{\circ} \mathrm{C}$ for $5 \mathrm{~min}$. The PCR mixture of $25 \mu \mathrm{l}$ included $1 \mu \mathrm{l}$ RT product as template, $2.5 \mu 110 \times$ buffer, $0.2 \mathrm{mM}$ dNTPs, $1 \mathrm{U}$ Taq DNA polymerase (Fermentas) and 25 pmol of each primer. The PCR products were electrophoresed on ethidium bromide stained $2.0 \%$ agarose gels.

\subsection{Estimation of DNA Damages}

\subsubsection{Comet Assay}

Portions of liver from all experimental groups were washed in cold buffer (Nacl; $75 \mathrm{mmol} / \mathrm{I}$, EDTA-2Na; 24 $\mathrm{mmol} / \mathrm{I}, \mathrm{PH} 7.5$ ) and minced with a pair of scissors and homogenized using a potter-type homogenizer. The cell suspensions were centrifuged at $4^{0} \mathrm{C}, 700 \mathrm{xg}$ for $10 \mathrm{~min}$. The supernatants were removed and the cells were resuspended 
Table 1. Primer Sequences and Accession No. of the Amplified Genes

\begin{tabular}{|c|c|c|c|}
\hline $\begin{array}{l}\text { cDNA MGI Accession. (bp) } \\
\text { No }\end{array}$ & Forward / Reverse primer & Ann. temp. $\left({ }^{\circ} \mathrm{C}\right)$. & Frag. Size \\
\hline$\beta$-actin NM_007393 & $\begin{array}{c}\text { 5'- ATATCGCTGCGCTGGTCGTC-3', } \\
\text { 5'- AGGATGGCGTGAGGGAGAGC-3' }\end{array}$ & 61 & 517 \\
\hline SOD MGI:1346172 & $\begin{array}{l}\text { 5'-AAGGCCGTGTGCGTGCTGAA-3', } \\
\text { 5'- CAGGTCTCCAACATGCCTCT-3' }\end{array}$ & 56 & 246 \\
\hline CAT MGI:1346174v & $\begin{array}{l}\text { 5'-GCAGATACCTGTGAACTGTC-3', } \\
\text { 5'-GTAGAATGTCCGCACCTGAG-3' }\end{array}$ & 55 & 229 \\
\hline
\end{tabular}

in cold buffer. The slides were prepared according to Singh et al. [20] and examined at 100 magnifications under a fluorescence microscope using a FITC filter. The level of DNA damage was determined in each slide by evaluating the frequency of five parameters ( Untailed \%, Tailed \%, Tail Length $(\mu \mathrm{m}), \%$ DNA in Tail and Tail Moment). The numbers of comet were calculated using TriTek CometScoreTM Freeware version 1.5. 50 cells were randomly analyzed per slide for a total of 100 cells per animal.

\subsubsection{Quantitation of DNA Fragmentation}

DNA fragmentation was quantified by diphenylamine (DPA) as described by Paradones et al. [21] on the liver cells of all investigated groups. The percentage of DNA fragmentation was taken as the ratio of DNA absorbance reading in the supernatant to total amount of DNA in pellet and supernatant. Absorbance was measured at $600 \mathrm{~nm}$ using a UVdouble beam spectrophotometer (Shimadzu 160A). DNA isolated from liver tissue of control and treated mice were electrophoresed on ethidium bromide stained $1.5 \%$ agarose gels [22]. DNA damage in mice liver was detected by the elevation of the percentage of DNA fragmentation and the visualization of DNA ladders upon gel electrophoresis in control and treated animals.

\subsubsection{Micronucleus Assay}

The bone marrow of the femur was flushed with fetal bovine serum into tubes, smeared on clean slides, and fixed with methanol. The slides were air-dried and stained with 5\% Giemsa for 5 minutes [23]. In each animal, 1000 cells were examined for measuring micronucleus $(\mathrm{MN})$ formation.

\subsection{Statistical Analysis}

The results of biomarkers were analyzed using the arithmetic mean, standard error and variance [ANOVA].

Genes expression levels were measured by TotalLab software, version 1.0.3684.27069. The results were normalized to the levels obtained for the $\beta$-actin gene by taking a ratio of the value obtained for the gene of interest to that of $\beta$-actin. The standard error and variance were calculated using [ANOVA].

The results of DNA damage (Miconucleus, DNA fragmentation and comet assay) were analyzed using the arithmetic mean, standard deviation and variance [ANOVA], Posthoc multiple comparisons tests [24].

\section{RESULTS}

\subsection{Lipid Peroxidation and Antioxidant Defense Systems in the Kidney and Liver Tissue}

Malondialdehyde (MDA) is the lipid peroxidation biomarker that measures the level of oxidative stress in an organism. In group III, MDA level increased in liver and kidney tissues compared with control groups and group IV. Diabetic animals fed on walnuts diet showed significant reduction in MDA level ( $3.13 \pm 0.08 \& 1.55 \pm 0.08$, respectively) compared to diabetic mice fed on basal diet $(6.26 \pm 0.08$ $\& 2.57 \pm 0.22$, respectively). No significant difference was detected in MDA level between positive and the negative control groups.

Biomarker antioxidant parameters of SOD, CAT and GSH measured in liver and kidney tissues recorded significant decrease in group III $(20.0 \pm 1.04 \& 7.03 \pm 0.6 ; 7.4 \pm 2.8 \&$ $5.9 \pm 0.38$ and $8.67 \pm 0.89 \& 3.79 \pm 0.26$, respectively) compared with group I $(37.0 \pm 2.57 \&$ \& $12.4 \pm 0.87 ; 24.1 \pm 4.4$ $\& 9.8 \pm 0.4$ and $12.03 \pm 1.2 \& 7.2 \pm 0.94$; respectively). Mice in group IV observed ameliorate in these parameters expressed by marker elevations in SOD, CAT and GSH to the normal levels of control group. No significant differences were detected in these parameters between positive and negative control groups (Table 2, Fig. 1, 2).

\subsection{Genes Expression Profile in Experimental Groups}

Expression levels of oxidative stress genes, superoxide dismutases $(S O D)$, catalase $(C A T)$ and glutathione peroxidase $(G P x)$ in kidney tissues of mice are summarized in (Table 3 and Fig. 3). The genes expressions were normalized with the expression values of the $\beta$-Actin gene. Expression levels of $S O D$ and $C A T$ genes were significantly decreased in the kidney tissues of group III compared to group IV and control groups. The expression levels of the two genes in group IV showed compensatory increase to normal level. No significant differences were detected between group IV and control groups as well as between the two control groups. The results of GPX gene revealed over-expression of this gene in kidney tissues of group III compared to control groups. In diabetic animals fed on walnuts diet, GPx gene over-expression was decreased $(2.1 \pm 0.26)$ compared to diabetic mice fed on basal diet group $(2.5 \pm 0.31)$. No significant differences were detected between negative and positive control groups. 
Table 2. Biomarkers Detection of Controls and Treated Groups

\begin{tabular}{|c|c|c|c|c|c|c|c|c|}
\hline \multirow{2}{*}{$\begin{array}{c}\text { Experimental } \\
\text { groups }\end{array}$} & \multicolumn{2}{|c|}{ Group I } & \multicolumn{2}{|c|}{ Group II } & \multicolumn{2}{|c|}{ Group III } & \multicolumn{2}{|c|}{ Group IV } \\
\hline & Liver & Kidney & Liver & Kidney & Liver & Kidney & Liver & Kidney \\
\hline $\begin{array}{c}\text { MDA } \\
\text { (nmol/mg protein) }\end{array}$ & $3.07 \pm 0.15^{\mathrm{a}}$ & $1.46 \pm 0.06^{\mathrm{a}}$ & $3.20 \pm 0.13^{\mathrm{a}}$ & $1.38 \pm 0.07^{\mathrm{a}}$ & $6.26 \pm 0.08^{b}$ & $2.57 \pm 0.22^{b}$ & $3.13 \pm 0.08^{\mathrm{a}}$ & $1.55 \pm 0.08^{\mathrm{a}}$ \\
\hline $\begin{array}{c}\mathrm{GSH}^{*} 10 \\
(\mu \mathrm{mol} / \mathrm{mg} \text { protein })\end{array}$ & $12.03 \pm 1.2^{\mathbf{b}}$ & $7.2 \pm 0.94^{\mathrm{b}}$ & $13.3 \pm 0.72^{\mathbf{b}}$ & $6.9 \pm 0.35^{\mathrm{b}}$ & $8.67 \pm 0.89^{a}$ & $3.79 \pm 0.26^{\mathrm{a}}$ & $13.43 \pm 0.97^{\mathbf{b}}$ & $6.21 \pm 0.3^{\mathbf{b}}$ \\
\hline $\begin{array}{c}\mathrm{SOD}^{*} 10 \\
(\mathrm{U} / \mathrm{mg} \text { protein })\end{array}$ & $37.0 \pm 2.57^{\mathbf{b}}$ & $12.4 \pm 0.87^{\mathbf{b}}$ & $33.8 \pm 1.1^{\mathbf{b}}$ & $11.5 \pm 0.73^{b}$ & $20.0 \pm 1.04^{\mathrm{a}}$ & $7.03 \pm 0.6^{\mathrm{a}}$ & $35.4 \pm 3.4^{\mathrm{b}}$ & $11.9 \pm 1.2^{\mathbf{b}}$ \\
\hline $\begin{array}{c}\mathrm{CAT}^{*} 10 \\
(\mathrm{U} / \mathrm{mg} \text { protein })\end{array}$ & $24.1 \pm 4.4^{\mathbf{b}}$ & $9.8 \pm 0.4^{\mathbf{b}}$ & $25.2 \pm 1.6^{\mathbf{b}}$ & $9.3 \pm 0.25^{\mathbf{b}}$ & $7.4 \pm 2.8^{\mathrm{a}}$ & $5.9 \pm 0.38^{\mathrm{a}}$ & $20.9 \pm 1.6^{\mathbf{b}}$ & $8.91 \pm 0.66^{\mathbf{b}}$ \\
\hline
\end{tabular}

Values are expressed as means \pm SEM. Means with different superscript letters are significantly different $(\mathrm{P}<0.05)$.

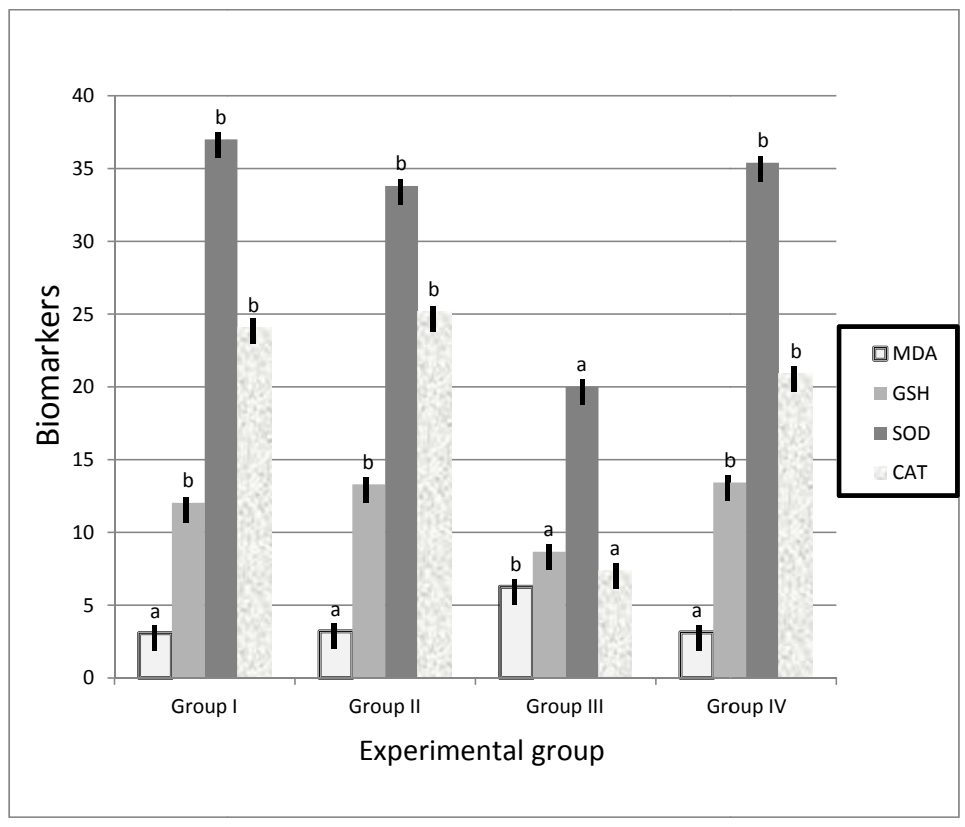

Fig. (1). Biomarker antioxidant parameters in liver of control and treated groups.

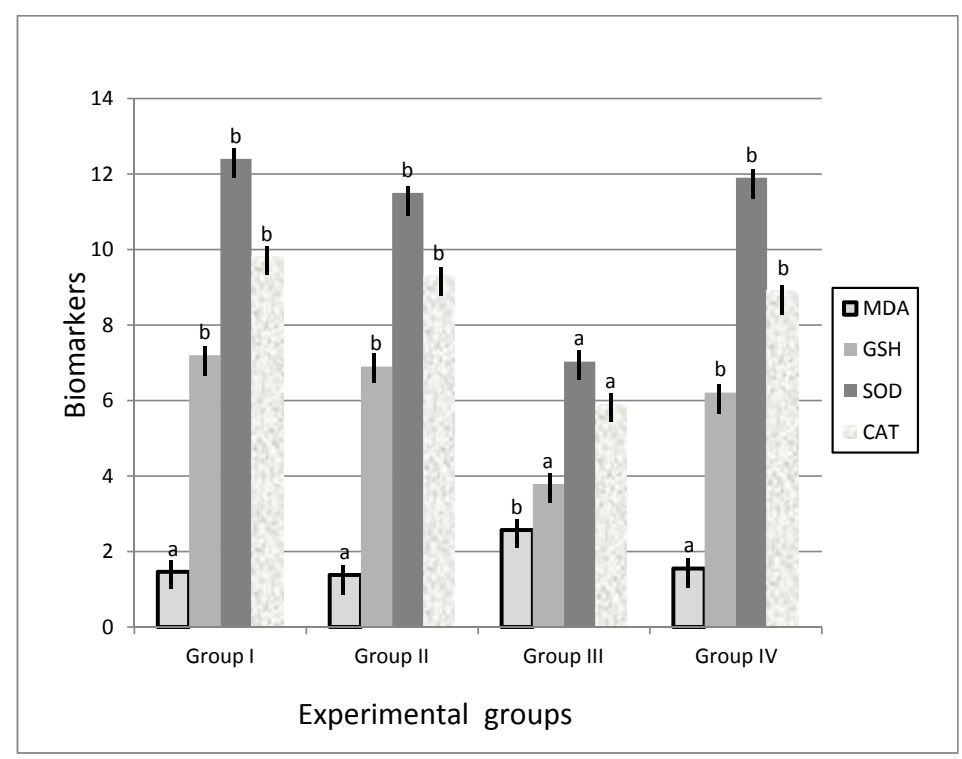

Fig. (2). Biomarker antioxidant parameters in kidney of control and treated groups. 
Table 3. Expression of Oxidative Stress Genes in the Kidney of Mice Determined by Semi-Quantitative RT-PCR

\begin{tabular}{|c|c|c|c|}
\hline Experimental animals groups & SOD & CAT & GPx \\
\hline \hline Group I & $2.6 \pm 0.42^{\mathrm{a}}$ & $1.93 \pm 0.09^{\mathrm{a}}$ & $1.85 \pm 0.1^{\mathrm{a}}$ \\
\hline Group II & $2.3 \pm 0.36^{\mathrm{a}}$ & $2.1 \pm 0.13^{\mathrm{a}}$ & $1.9 \pm 0.2^{\mathrm{a}}$ \\
\hline Group III & $1.57 \pm 0.25^{\mathrm{b}}$ & $1.02 \pm 0.08^{\mathrm{b}}$ & $2.5 \pm 0.31^{\mathrm{b}}$ \\
\hline Group IV & $1.94 \pm 0.37^{\mathrm{ab}}$ & $1.75 \pm 0.12^{\mathrm{a}}$ & $2.1 \pm 0.26^{\mathrm{b}}$ \\
\hline
\end{tabular}

Values are expressed as means \pm SEM Means with different superscript letters are significantly different $(\mathrm{P}<0.05)$.

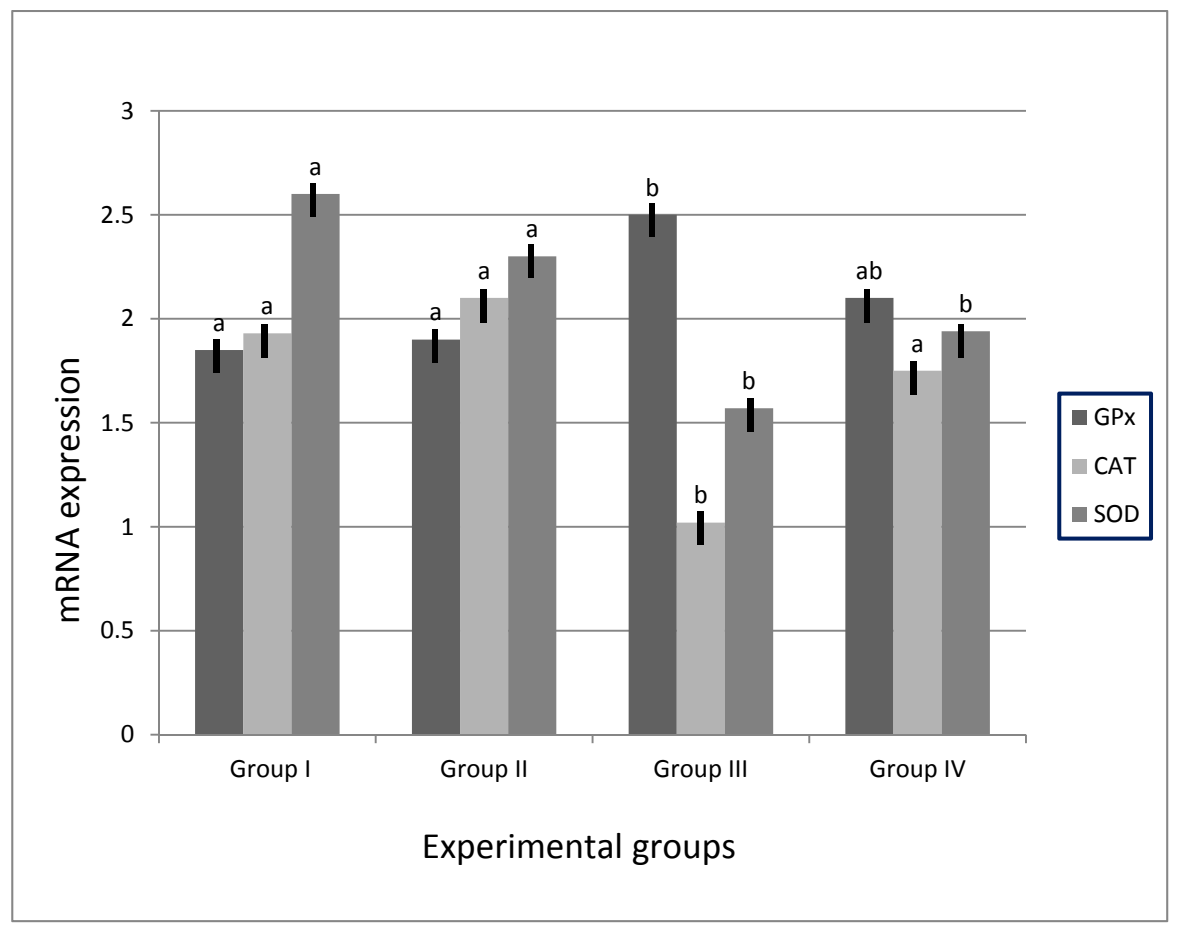

Fig. (3). SOD, CAT and GPx mRNA expression in mice's kidney of control and treated groups.

\subsection{Evaluation of DNA Damages}

\subsubsection{Comet Assay}

Quantitative analysis of the single cell gel electrophoresis (SCGE) or comet assay yielded several indices of DNA damage, including untailed $\%$, tailed $\%$, Tail Length $(\mu \mathrm{m}), \%$ DNA in Tail and Tail Moment. The indices of DNA damage recorded by comet assay were significantly increased in group III compared to other groups. Comparative analysis between group III and group IV indicated that the DNA damage significantly decreased in diabetic mice fed on walnuts diet compared to diabetic mice fed on basal diet (group III). Negative and positive control groups showed significant differences in the three parameters of comet assay (Table 4).

\subsubsection{DNA Fragmentation}

DNA fragmentation in control and treated animals is shown in (Table 5). DNA fragmentation recorded highly significant difference in diabetic animals compared to control groups. Comparative study between mice in group III and group IV illustrated that the DNA fragmentation in group IV was significantly decreased. Negative and positive control groups showed significant differences $(8.54 \pm 0.75$ and $12.49 \pm 0.31$, respectively).

The DNA fragmentation patterns in control and treated animals are shown in (Fig. 4). A clear smear of DNA down in lane 3 was observed (group III). The negative and positive control groups showed discrete bands near the wells and clear dark band at the same level (lanes 1 and 2, respectively). Group IV presented as discrete bands near the well and dark band in level different than that found in control groups (lane 4).

\subsubsection{Micronucleus Analysis}

Micronucleus $(\mathrm{MN})$ frequencies in control and treated animals are shown in (Table 6). The MN frequency in group III expressed significant difference $(18.75 \pm 0.75)$ compared to group I and II (7.75 \pm 0.47 and $13.0 \pm 1.0$, respectively). Mice in group IV recorded significant decrease in $\mathrm{MN}$ frequency compared to group III. . Negative and positive control groups showed significant differences $(7.75 \pm 0.47$ and $13.0 \pm 1.0$, respectively). 
Table 4. The Single-Cell Gel Electrophoresis Technique or Comet Assay in Treated and Control Groups

\begin{tabular}{|c|c|c|c|c|}
\hline DNA Damage & Group I & Group II & Group III & Group IV \\
\hline \hline Untailed \% & $98 \pm 1.82^{\mathbf{b}}$ & $95 \pm 1.87^{\text {ab }}$ & $90.5 \pm 2.0^{\mathbf{a}}$ & $93 \pm 1.95^{\text {ab }}$ \\
\hline Tailed \% & $2 \pm 0.4^{\mathbf{a}}$ & $5 \pm 0.9^{\mathbf{b}}$ & $8.75 \pm 1.1^{\mathbf{c}}$ & $7 \pm 0.91 \mathrm{~b}^{\mathbf{c}}$ \\
\hline Tail Length( $\mu \mathrm{m})$ & $1.18 \pm 0.08^{\mathbf{a}}$ & $1.69 \pm 0.1^{\mathbf{b}}$ & $3.03 \pm 0.2^{\mathbf{c}}$ & $2.88 \pm 0.17^{\mathbf{c}}$ \\
\hline$\%^{\mathbf{c}}$ DNA in Tail & $1.04 \pm 0.1^{\mathbf{a}}$ & $1.53 \pm 0.3^{\mathbf{a}}$ & $3.0 \pm 0.1^{\mathbf{c}}$ & $2.36 \pm 0.12^{\mathbf{b}}$ \\
\hline Tail Moment & $1.29 \pm 0.13^{\mathbf{a}}$ & $3.48 \pm 0.14^{\mathbf{b}}$ & $8.97 \pm 0.32^{\mathbf{d}}$ & $6.71 \pm 0.14^{\mathbf{c}}$ \\
\hline
\end{tabular}

Within each raw means superscript with different letters are significantly different $(\mathrm{P} \leq 0.05)$.

Table 5. DNA Fragmentation in Mice's Liver of Treated and Control Groups

\begin{tabular}{|c|c|c|c|}
\hline \multirow{2}{*}{ Treatments } & \multicolumn{2}{|c|}{ DNA fragmentation. } & \multirow{2}{*}{ Change \% } \\
\cline { 2 - 4 } & Rang & Mean \pm S.E. & \\
\hline \hline Group I & $7.28 \pm 10.62$ & $8.54 \pm 0.75^{\mathbf{a}}$ & 3.95 \\
\hline Group II & $9.91 \pm 12.49$ & $12.49 \pm 0.31^{\mathbf{b}}$ & 21.61 \\
\hline Group III & $28.5 \pm 32.4$ & $30.15 \pm 0.88^{\mathbf{d}}$ & 17.54 \\
\hline Group IV & $23.05 \pm 28.06$ & $26.08 \pm 1.0^{\mathbf{c}}$ & \\
\hline
\end{tabular}

Within each raw means superscript with different letters are significantly different $(\mathrm{P} \leq 0.05)$.

\section{$\begin{array}{lllll}M & 1 & 2 & 3 & 4\end{array}$}

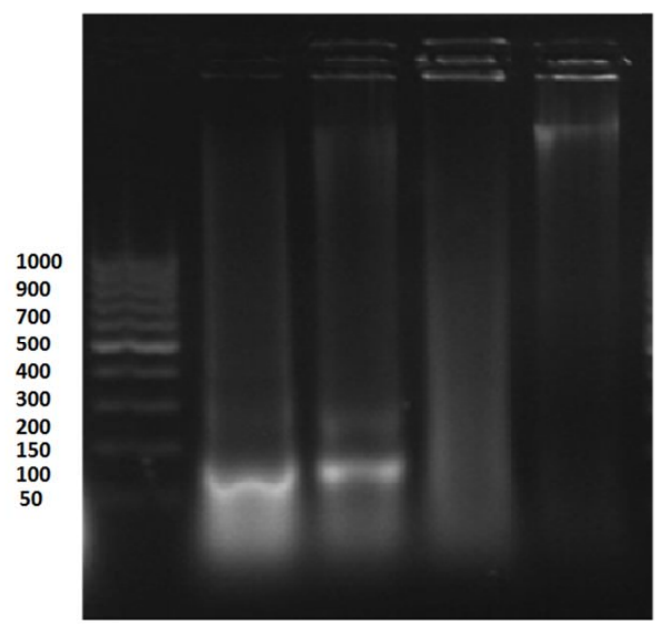

Fig. (4). Agarose gel electrophoretic pattern of DNA isolated from liver tissue of control and treated mice. M: DNA ladder; Lane 1: negative control group; Lane 2: positive control group; Lane 3: diabetic mice group fed on basal diet; Lane 4: diabetic mice group fed on walnuts mixture diet.

\section{DISCUSSION}

Achievement of effective and safe therapeutic drugs is the main target of drug discovery. Recently, scientists work on building a therapeutic regimen that optimizes the efficacy of the therapy while at the same time limiting potential adverse or toxic side effects. Natural substances are the main sources of therapeutic drugs that provide less adverse effect than synthetic therapeutic drugs [9]. Walnuts contents have several antioxidants, which can fight the free-radical damage that contributes to cancer, heart disease, premature aging and cell death [25-27].

Table 6. Frequencies of Micronucleated Polychromatic Erythrocytes Induced in Treated and Control Groups in Bone Marrow Cells

\begin{tabular}{|c|c|c|}
\hline $\begin{array}{c}\text { Experimental } \\
\text { groups }\end{array}$ & $\begin{array}{c}\text { Total Counted } \\
\text { PCEs/mice }\end{array}$ & Mean \pm S.E. \\
\hline \hline Group I & 2000 & $7.75 \pm 0.47^{\mathbf{a}}$ \\
\hline Group II & 2000 & $13.0 \pm 1.0^{\mathbf{b}}$ \\
\hline Group III & 2000 & $18.75 \pm 0.75^{\mathbf{c}}$ \\
\hline Group IV & 2000 & $15.0 \pm 0.91^{\mathbf{b}}$ \\
\hline
\end{tabular}

Within each raw means superscript with different letters significantly different $(\mathrm{P} \leq 0.05)$.

The Study of pharmacogenomics and biochemical influences of walnuts on diabetic tissue complies with drug discovery focus on effective treatment without/less adverse effect. The effect of walnuts antioxidant on induced diabetic mice was investigated. Type 1 diabetes was induced by i.p. injection of STZ for 3 successive days. Mice were considered diabetic when the blood glucose concentrations increased to 200 or more $\mathrm{mg} / \mathrm{dl}$. Experimental animals were divided into four groups (negative and positive control, diabetic group and diabetic group fed on walnuts diet). Walnuts influence on control and diabetic tissues was assessed using biochemical markers, genes expression and DNA damage assays. 
Biomarker is objectively measured and evaluated as an indicator of normal biologic processes, pathogenic processes, or pharmacologic responses to a therapeutic intervention. Superoxide dismutase (SOD), Catalase (CAT) and Glutathione (GSH) reported to be used as biomarker indices to evaluate the formation of free radicals. SOD constitutes the first line of defense against reactive O2 species (ROS). Specialization of function among the SOD may be due to a combination of influence of subcellular location of the enzyme and upstream sequences in genomic sequence [28]. CAT is major function within cells is to prevent the accumulation of toxic levels of hydrogen peroxide formed as a byproduct of metabolic processes - primarily that of the electron transport pathway [29]. GSH is often referred to as the body's master antioxidant and essential component to the body's natural defense system [30]. In patients with diabetes mellitus, free radical-induced damage arises from an imbalance between pro-oxidant and antioxidant systems [31]. The results of diabetic mice fed on basal diet showed significant decrease of SOD, CAT and GSH levels in liver and kidney tissues, while diabetic animals fed on walnuts diet showed marker elevations in SOD, CAT and GSH to the normal levels of control groups (Table 2). MDA level increased in liver and kidney tissues of diabetic group $(6.26 \pm 0.08$ and $2.57 \pm 0.22$, respectively), while walnuts treated diabetic animals afforded a significant reduction in MDA level $(3.13 \pm 0.08$ and $1.55 \pm 0.08$, respectively). MDA level increase in diabetes traced back to the hyperglycemia which induces carbonyl stress and lead to increased lipid peroxidation and oxidative damage due to increase of peroxy radicals and hydroxyl radicals [32-34]. Our results of biochemical analysis suggested that the walnuts antioxidant substances act to quench the oxidative stress in diabetic tissues, which could not be removed by diabetic mice's antioxidant systems.

Applications of pharmacogenomics are of interest to industry, clinicians, academics, and patients alike. For the biopharmaceutical industry, pharmacogenomics can improve the drug development process through faster and safer drug trials and the early identification of drug responders, nonresponders, and those prone to adverse events [14]. Gene expression is combined with metabolic schemas to understand how pathways are changed under varying conditions. The expression levels of $S O D, C A T$ and GPX genes in diabetic mice of our study were in agreement with recent studies reporting that the mRNA expressions of $S O D$ and $C A T$ decreased, while the GPx increased with higher plasma glucose concentrations in diabetes $[7,35,36]$. The results of expression levels of oxidative stress genes studied in kidney tissues of mice fed on walnuts diet showed that the $S O D$ and $C A T$ genes expression levels were compensatory increased to normal level (Table 3), while GPx gene over-expression in diabetic mice $(2.5 \pm 0.31)$ decreased with walnuts treatment $(2.1 \pm 0.26)$. No significant differences were found between diabetic mice fed on walnuts diet and control groups. These results suggested that the expression levels of these genes were associated with the respective activities of antioxidant enzymes tested and walnuts treatment act to improve genes expression to normal.

Regulatory authorities all over the world require data on the genotoxic potential of new drugs chemical compounds, as part of the safety evaluation process. Genotoxicity assays became an integral component of regulatory requirements. It can be defined as in vitro and in vivo tests designed to detect compounds that induce genetic damage by various mechanisms. Comet assay is a sensitive technique for measuring and analyzing DNA breaks in various mammalian cells [20, $37,38]$. It is widely used in areas of research ranging from biomonitoring and studies of DNA damage processes to routine assessments of genotoxicity [39-41]. DNA damage with the frequencies of comet untailed, tails, tail moment, \%DNA in tail and tail length have been detected in all tested animals. The results illustrated that the walnuts reduce the DNA damage in group IV compared to group III. The comet assay results suggested that the walnuts treatment decrease cells necrosis.

DNA fragmentation, used to study apoptosis in cell populations. DNA damage in mice liver was detected by visualization of the DNA of tested animals upon gel electrophoresis (Fig. 4). The gel represented the genomic DNA degraded in different groups. The smear of DNA down in lane3 (diabetic mice) indicated that the DNA genome of diabetic mice degraded into thousands of smaller fragments. Darker bands present in lanes 1, 2 and 4 (Fig. 4) indicated that these samples contained less apoptosis and more live cells expressed in clear dark DNA band. The DNA fragmentation results clarified that the walnuts treatment in diabetic mice decreased the DNA fragmentation.

Micronucleus test is widely employed in different areas as biological monitoring. Micronuclei are small chromatin containing bodies arising from chromosome fragments or whole chromosome that were not incorporated into daughter nuclei following mitosis [42]. The result of MN frequency showed higher significant difference between Streptozotocin treated animals and control groups (Table 6). The diabetic animals in group IV fed on walnuts diet showed significant decrease in MN frequency compared to diabetic animals fed on basal diet. The micronucleus assay results confirmed the positive influence induced by walnuts treatment in diabetic animals.

Evaluating the results of negative and positive controls clarified that there were no significant differences between the two groups at the metabolic activity and expression levels of tested genes. While using DNA fragmentation, micronucleus and comet assays showed significant differences at $\mathrm{P}$ $<0.05$ between negative and positive control. These results could be referred to the accuracy of these assays that precisely measure the minor adverse effect of compounds. This level of adverse effect on DNA damage could be withdrawn with normal DNA repair processes [43].

In conclusion, pharmacogenomics and biochemical assays have potential value for assessing and monitoring the effectiveness and safety of pharmaceutical and medicinal therapy. The results suggested that walnuts could act as diabetic therapy without adverse effects at metabolic activity and molecular levels in diabetic mice.

\section{CONFLICT OF INTEREST}

The author(s) confirm that this article content has no conflicts of interest. 


\section{ACKNOWLEDGEMENT}

Declared none.

\section{REFERENCES}

[1] Mohamed AK, Bierhaus A, Schiekofer S, et al. The role of oxidative stress and NF- $\beta$ activation in late diabetic complication. Biofactors $1999 ; 10$ : 171-9

[2] Nammi S, Boini MK, Lodagala DS, Behara RB. The juice of fresh leaves of Catharanthus rosesus Linn reduces blood glucose in normal and alloxan diabetic rats. BMC Complement Altern 2003; 3: 14.

[3] Maxwell SR, Thopson H, Sandler D, et al. Antioxidant status in patient with uncomplicated insulin-dependent and noninsulin dependent diabetes mellitus. Eur J Clin Invest 1997; 27: 484-90.

[4] Santini SA, Marra G, Giardina B, et al. Defective plasma antioxidant defenses and enhanced susceptibility to lipid peroxidation in uncomplicated IDDM. Diabetes 1997; 46: 1853-8.

[5] Gutteridge JM, Halliwell B. Free radicals and antioxidants in the year 2000. A historical look to the future. Ann N Y Acad Sci 2000; 899: $136-47$

[6] McCord JM. The evolution of free radicals and oxidative stress. Am J Med 2000; 108: 652-9.

[7] Sadi G, Guray T. Gene expressions of Mn-SOD and GPx-1 in streptozotocin induced diabetes: effect of antioxidants. Mol Cell Biochem 2009; 327: 127-34.

[8] Inoue H, Murakami HM, Matsumoto M, Kaji Y. Oxidative and Anti-oxidative Status in Blood of Streptozotocin-induced Diabetic Piglets. Asian-Aust. J Anim Sci 2011; 24(6): 818-24.

[9] Suba V, Murugesan T, Arunachalam G, Mandal SC, Saha BP. Anti-diabetic potential of Barleria lupulina extract in rats. Phytomedicine 2004; 11(2-3): 202-5.

[10] Rahman AU, Zaman K. Medicinal plants with hypoglycaemic activity. Ethnopharmacology 1989; 26: 1-55.

[11] Vinson JA, Cai Y. Nuts, especially walnuts, have both antioxidant quantity and efficacy and exhibit significant potential health benefits. Food Funct 2012; 3(2):134-40.

[12] Fukuda T, Ito H, Yoshida T. Antioxidative polyphenols from walnuts (Juglans regia L.). Phytochemistry 2003; 63: 795-801.

[13] Hamad E, Arthur MD, Feldman M. Pharmacogenetics in Heart Failure: How it will Shape the Future. Heart Fail Clin 2010; 6(1): $1-10$

[14] Karczewski KJ, Daneshjou R, Altman RB. Pharmacogenomics. PLoS ONE 2012; 8 (12): 1-18.

[15] Abdel Wahab YH, O'Harte FP, Ratcliff H, et al. Glycation of insulin in the islets of Langerhans of normal and diabetic animals. Diabetes 1996; 45: 1489-96.

[16] Bradford MM. A rapid and sensitive method for the quantitation of microgram quantities of protein utilizing the principle of proteindye binding. Anal Biochem 1976; 7(72): 248-54.

[17] Aebi H. Catalase in vitro. In: methods in Enzymology. New York: Academic Press, 1984; pp. 479-500.

[18] El Moutassim, Guerin P, Menezo Y. Expression of genes encoding antioxidant enzymes in human and mouse oocytes during the final stages of maturation. Mol Hum Reprod 1999; 5 (8): 720-5.

[19] Qing-Song G, Yan Z, Lei W, et al. Combined transfection of the three transcriptional factors, PDX-1, neuroD1, and MafA, causes differentiation of bone marrow mesenchymal stem cells into insulin-producing cells. Exp Diabetes Res 2012; 2012: 10-20.

[20] Singh NP, McCoy MT, Tice RR, Schneider EL. A simple technique for quantitation of low levels of DNA damage in individual cells. Exp Cell Res 1988; 175: 184-91.

[21] Paradones CE, Illera VA, Peckham D, Stunz LL, Ashman RF. Regulation of apoptosis in vitro in mature spleen T cell. J Immunol 1993; 151: 3521 .
[22] Yokozawa T, Dong E. Role of ginsenoside-Rd in cisplatin-induced renal injury: special reference to DNA fragmentation. Nephron 2001; 9: 433-8.

[23] Salamone M, Heddle J, Stuart E, Katz M. Towards an improved micronucleus test: studies on 3 model agents, mitomycin $\mathrm{C}$ cyclophosphamide, and dimethylbezanthracene. Mutat Res 1980; 74: 347-56.

[24] Pipkin BF. Medical statistics made easy. $5^{\text {th }}$ ed., New York, USA Churchill Livingstone, 1984; pp. 46-56.

[25] Blomhoff R, Carlsen MH, Lene Frost Andersen LF, Jacobs D. Health benefits of nuts: potential role of antioxidants. Br J Nutr 2006; 96(2): S52-60.

[26] McKay DL, Chen O, Yeum KJ, et al. Chronic and acute effects of walnuts on antioxidant capacity and nutritional status in humans: a randomized, cross-over pilot study. Nutr J 2010; 9: 21-31

[27] Rahimi P, Kabiri N, Asgary S, Setorki M. Anti-diabetic effects of walnut oil on alloxan-induced diabetic rats. Aust J Plant Physiol 2011; 5(24): 2655-61.

[28] Aslscher RG, Erturk N, Health LS. Role of superoxide dismutases (SODS) in controlling oxidative stress in plants. J Exp Bot 2002; 53(372): 1331-41.

[29] Ścibior D, Czeczot H. Catalase: structure, properties, functions Postepy Hig Med Dosw 2006; 60: 170-80.

[30] Meister A. Glutathione metabolism and its selective modification. J Biol Chem 1988; 263(33): 17205-8.

[31] Bonnefont-Rousselot D, Bastard JP, Jaudon MC, Delattre J. Consequences of the diabetic status on the oxidant/antioxidant balance. Diabetes Metab 2000; 26:163-76.

[32] Bayanes JW, Thrope SR. Role of oxidative stress in diabetic complications: a new perspective on an old paradigm. Diabetes 1999; 48: $1-9$.

[33] Levy U, Zaltzber H, Ben-Amotz A, Kanter Y, Aviram M. $\beta$ carotene affects antioxidant status in noninsulin-dependent diabetes mellitus. Pathophysiology 1999; 6: 157-61.

[34] Montilla , Barcos M, Muñoz MC, et al. Red Wine Prevents Brain Oxidative Stress and Nephropathy in Streptozotocin-induced Diabetic Rats. J Biochem Mol Biol 2005; 38(5): 539-44.

[35] Sadi G, Yilmaz O, Güray T. Effect of vitamin C and lipoic acid on streptozotocin-induced diabetes gene expression: mRNA and protein expressions of $\mathrm{Cu}-\mathrm{Zn} \mathrm{SOD}$ and catalase. Mol Cell Biochem 2008; 309: 109-16.

[36] Matsunami T, Sato Y, Sato T, et al. Oxidative stress and gene expression of antioxidant enzymes in the streptozotocin-induced diabetic rats under hyperbaric oxygen exposure. Int $\mathrm{J}$ Clin Exp Pathol 2010; 3(2): 177-88.

[37] Ostling O, Johanson KJ. Microelectrophoretic study of radiationinduced DNA damages in individual mammalian cells. Biochem Biophys Res Commun 1984; 123: 291-8.

[38] Olive PL, Banáth JP, Durand RE. Heterogeneity in radiationinduced DNA damage and repair in tumor and normal cells measured using the "Comet" assay. Radiat Res 1990; 122: 86-94.

[39] Tice RR, Agurell E, Anderson D, et al. Single cell gel/comet assay: guidelines for in vitro and in vivo genetic toxicology testing. Environ Mol Mutagen 2000; 35: 206-11.

[40] Liao W, McNutt MA, Zhu WG. The comet assay: a sensitive method for detecting DNA damage in individual cells. Methods 2009; 48: 46-53

[41] McArt DG, McKerr G, Howard CV, Saetzler K, Wasson GR Modelling the comet assay. Biochem Soc Trans 2009; 37: 914-7.

[42] Mavournin KH, Blakey DH. Cimino MC, Salamone MF, Heddle $\mathrm{JA}$. The in vivo micronucleus assay in mammalian bone marrow and peripheral blood. A report of U.S. Environmental protection Agency Gene-tox program. Mutat Res 1990; 393: 29-80.

[43] Alberts B, Johnson A, Lewis J, et al. Molecular Biology of the Cell. $4^{\text {th }}$ ed. New York: Garland Science: 2002.

This is an open access article licensed under the terms of the Creative Commons Attribution Non-Commercial License (http://creativecommons.org/licenses/by-nc/3.0/) which permits unrestricted, non-commercial use, distribution and reproduction in any medium, provided the work is properly cited. 